\title{
INTERVENSI SELF-REGULATION EMPOWERMENT PROGRAM UNTUK MENINGKATKAN MOTIVASI BERPRESTASI MAHASISWA NON REGULER DI JURUSAN X UNIVERSITAS $X$
}

\author{
Budi Sulaeman $^{1}$, Riana Sahrani ${ }^{2}$ dan Sesilia Monika ${ }^{3}$ \\ ${ }^{1}$ Fakultas Psikologi, Universitas Tarumanagara, Jakarta \\ Email: budi.291088@gmail.com \\ ${ }^{2}$ Fakultas Psikologi, Universitas Tarumanagara, Jakarta \\ Email: rianas@fpsi.untar.ac.id \\ ${ }^{3}$ Fakultas Psikologi, Universitas Tarumanagara, Jakarta \\ Email: sesiliam@fpsi.untar.ac.id
}

\begin{abstract}
ABSTRAK
Penelitian ini bertujuan untuk meningkatkan motivasi berprestasi pada mahasiswa non reguler melalui SelfRegulation Empowerment Program (SREP). Subyek penelitian ini adalah 16 mahasiswa non reguler dari Jurusan $X$, Universitas $X$ yang sedang menempuh jenjang semester 3. Subyek terbagi dalam dua kelompok yakni 8 mahasiswa pada kelompok eksperimen dan 8 mahasiswa lainnya pada kelompok kontrol dengan jumlah 6 perempuan dan 2 laki-laki pada masing-masing kelompok. Desain pada penelitian ini yakni kuasi eksperimen dengan desain pre-test-post-test non equivalent control group. Instrumen pengumpulan data yang digunakan pada penelitian ini menggunakan alat ukur motivasi berprestasi yang dikembangkan berdasarkan teori McClelland mengenai ciri-ciri individu yang mempunyai motivasi berprestasi. Teknik analisis data menggunakan perhitungan uji beda 2 kelompok dengan kriteria statistik non parametrik yakni Mann-Whitney. Perhitungan dilakukan dengan membandingkan hasil data post-test motivasi berprestasi kelompok kontrol dan eksperimen. Berdasarkan perhitungan uji beda, didapatkan skor sig (2-tailed) sebesar 0,027 < 0,05. Hal ini menjelaskan bahwa Ha diterima dan Ho ditolak artinya intervensi Self-Regulation Empowerment Program dapat meningkatkan motivasi berprestasi mahasiswa non reguler Jurusan X, Universitas X.
\end{abstract}

Kata Kunci: self-regulation empowerment program, self-regulated learning. motivasi berprestasi, mahasiswa non reguler,

\section{PENDAHULUAN}

Prestasi akademik merupakan kajian yang sangat menarik khususnya dalam bidang psikologi pendidikan. Hal ini disebabkan prestasi akademik merupakan salah satu tolok ukur keberhasilan seseorang dalam dunia akademis (El-enzi dikutip dalam Latipah, 2010). Sementara itu, prestasi akademik ditentukan oleh dua faktor yakni internal dan eksternal. Faktor internal adalah faktor psikologi yang terdiri dari inteligensi (kapasitas kecerdasaan), sikap minat, bakat, motivasi, kemampuan mengatur diri dan faktor fisiologis. Adapun faktor eksternal meliputi pola asuh orangtua, lingkungan belajar, fasilitas pembelajaran dan kualitas pendidik (Gunarsa dalam Latipah, 2010).

Motivasi merupakan faktor terpenting yang akan memengaruhi individu dalam bertindak untuk mencapai tujuan. Menurut Zimmerman (2000), motivasi merupakan dampak yang vital bagi pencapaian prestasi individu. Penguatan pada faktor internal yakni motivasi berprestasi menjadi sangat penting karena bersifat menetap dibanding penguatan dilakukan pada faktor eksternal.

Menurut Gunarsa (2008) motivasi merupakan suatu dorongan atau suatu kehendak yang mendasari nampaknya suatu tingkah laku. Motivasi dapat diartikan sebagai tenaga pendorong 
untuk melakukan suatu hal atau menampilkan suatu perilaku tertentu. Motivasi dalam kajian psikologi pendidikan dikenal dengan istilah motivasi berprestasi.

Motivasi berprestasi pada hakekatnya adalah keinginan, hasrat, kemauan dan pendorong untuk dapat unggul, yaitu melebihi prestasi yang pernah dicapainya sendiri atau prestasi orang lain (Nicholl dalam Purwanto, 2014). Motivasi berprestasi berkontribusi terhadap capaian prestasi akademik. Hal ini sejalan dengan penelitian yang dilakukan oleh Sugiyanto (2009) bahwa motivasi berprestasi mempunyai korelasi positif dan berkontribusi terhadap prestasi akademik. Sementara itu, Menurut McClelland (dalam Haryani \& Tarias, 2014) menjelaskan bahwa individu dengan need for achievement yang rendah mempunyai karakteristik yakni memilih tugas-tugas yang cenderung mudah, cenderung mudah menyerah jika mengalami hambatan atau masalah serta tidak suka terhadap tantangan.

Fenomena rendahnya motivasi berprestasi yang berdampak pada pencapaian prestasi tentunya dialami oleh pembelajar baik pada siswa sampai dengan mahasiswa. Hal ini juga dialami oleh mahasiswa di Universitas X. Saat ini, Universitas X menghadapi fenomena yakni para mahasiswa mempunyai capaian hasil prestasi akademik tergolong rendah. Sesuai dengan kebijakan Universitas $\mathrm{X}$ bahwa para mahasiswa tersebut dengan prestasi yang rendah disebut mahasiswa non reguler.

Istilah mahasiswa non reguler digunakan oleh Universitas $\mathrm{X}$ untuk menggolongkan mahasiswa berdasarkan tiga kriteria yakni (1) mahasiswa yang mempunyai pencapaian indeks kumulatif prestasi (IPK) kurang dari 2,00, (2) mahasiswa dengan capaian satuan kredit semester (SKS) kumulatifnya masih kurang dan tidak sesuai, (3) mahasiswa yang mempunyai IPK kurang dari 2,00 dan masih mempunyai kekurangan dalam jumlah satuan kredit semester. Berdasarkan data yang dilansir oleh unit khusus di Universitas X yang merekap data mengenai hasil capaian studi seluruh mahasiswa menunjukkan bahwa Jurusan $\mathrm{X}$ adalah Jurusan dengan jumlah mahasiswa non regular terbanyak.

Merujuk pada hasil komunikasi personal kepada Ibu LRC salah satu dosen di Jurusan X dan wawancara kepada lima mahasiswa non reguler, didapatkan hasil bahwa kegagalan dalam menerapkan Self-Regulated Learning merupakan faktor penyebab utama yang membuat para mahasiswa tergolong sebagai mahasiswa non reguler.

Self-regulated learning dimaknai sebagai salah satu aspek yang menjadi penggerak utama kepribadian manusia (Boeree dalam Alfiana, 2013). Berdasarkan hal tersebut, perlu diberikan intervensi Self-Regulated Learning. Menurut Zimmerman (2001) menunjukkan Self-Regulated Learning mempunyai korelasi yang signifikan terhadap peningkatan motivasi berprestasi yang berdampak pada prestasi akademis.

Cleary dan Zimmerman (2004) memperkenalkan sebuah program pelatihan Self-Regulated Learning disebut sebagai Self-Regulation Empowerment Program (SREP). Self-Regulation Empowerment Program adalah program pelatihan yang diterapkan di sekolah dengan mengintegrasikan banyak esensi penting dari pendekatan pemecahan masalah dengan menggunakan siklus regulasi diri dalam belajar (Cleary \& Zimmerman, 2004).

Tujuan dari pelatihan Self-Regulation Empowerment Program yakni (1) memupuk keyakinan motivasi diri yang positif, (2) meningkatkan pengetahuan siswa mengenai strategi belajar dan (3) 
membantu siswa untuk mengaplikasikan strategi tersebut pada tugas akademik secara mandiri (Cleary \& Zimmerman, 2004).

Berdasarkan hasil penelitian yang telah dilakukan oleh Puteri dan Andranita (2013) menunjukkan bahwa penerapan intervensi Self-Regulation Empowerment Program dapat meningkatkan kemampuan Self-Regulated Learning pada siswa underachiever. Namun demikian, belum terdapat penelitian yang menerapkan program intervensi ini dalam hal meningkatkan motivasi berprestasi serta dilakukan pada mahasiswa sehingga penelitian ini perlu dilakukan guna memberi penangan secara tepat pada mahasiswa non reguler.

Merujuk pada fenomena di Jurusan X Universitas X mengenai mahasiswa non reguler Maka hal ini perlu dikaji secara mendalam perihal penerapan program pelatihan Self-Regulation Empowerment Program terhadap peningkatan motivasi berprestasi para mahasiswa non reguler Jurusan X Universitas X.

\section{Motivasi Berprestasi}

Studi mengenai motivasi berprestasi dimulai dari taksonomi Murray yang mengenai sistem kebutuhan dan dilanjutkan dengan perkembangan TAT (Thematic Apperception Test) untuk mengetahui gambaran motif individu (Schunk, Pitrich \& Meece, 2012). Menurut Atkinson's (dikutip dalam Schunk, Pitrich \& Meece, 2012) menyatakan motivasi berprestasi adalah kombinasi dari kebutuhan, pengharapan dan nilai. Ketiga aspek tersebut menjadi satu kesatuan yang bersifat komprehensif.

Menurut Deci dan Ryan (dikutip dalam Schunk, Pitrich \& Meece, 2012) motivasi terbagi menjadi 3 jenis yakni motivasi intrinsik, motivasi ekstrinsik dan tidak termotivasi.Teori determinasi diri ini kemudian terbagi menjadi beberapa subteori yaitu: teori evaluasi kognitif (cognitive evaluation theory, CET) untuk menjelaskan sisi motivasi intrinsik dan ekstrinsik pada manusia.

Menurut Deci dan Ryan (dikutip dalam Schunk, Pitrich \& Meece, 2012) Motivasi intrinsik adalah suatu kebutuhan manusia untuk merasa kompeten dan memiliki determinasi diri dalam berhubungan dengan lingkungannya. Motivasi ekstrinsik adalah motivasi untuk melibatkan diri dalam suatu aktivitas sebagai suatu cara untuk menggapai sebuah tujuan. Tidak termotivasi adalah individu tidak merasa kompeten (keefektifan diri rendah, keyakinan kapasitas rendah) terdapat persepsi non syarat antara perilaku dengan hasil.

Deci (dikutip dalam Schunk, Pitrich \& Meece, 2012) mengemukakan tiga sumber motivasi atau pengaturan diri ekstrinsik yang membuat individu termotivasi yaitu: (a) pengaturan eksternal (external regulation), (b) pengaturan introjeksi (introjected), dan (c) pengaturan identifikasi (identified).

Pengaturan eksternal (external regulation) adalah tahapan individu pada tahap awal mungkin tidak ingin melakukan tugasnya, namun pada akhirnya mengambil keputusan untuk melakukan tugas tersebut guna memperoleh penghargaan dan menghindari hukuman. Pengaturan introjeksi (introjected) adalah tahapan dimana individu melakukan tugasnya untuk menghindari rasa bersalah yang akan timbul bila individu tersebut tidak menyelesaikan tugasnya. Sementara itu, pengaturan Identifikasi (identified) merupakan tahap dimana individu terlibat dalam aktivitas karena secara pribadi penting bagi mereka. 
Menurut McClelland (1987) merumuskan delapan indikator atau ciri-ciri individu dengan motivasi berprestasi yakni (1) suka bekerja keras, (2) ulet atau tekun, (3) membutuhkan umpan balik secara nyata, (4) berorientasi pada masa depan, (5) tidak suka membuang waktu, (6) optimis, (7) bertanggung jawab dan (8) memperhitungkan risiko. Selain itu, Identifikasi elemenelemen esensial dari motivasi berprestasi yakni efikasi diri atau self-efficacy, nilai tugas atau task value dan orientasi tujuan atau goal setting (Schunk, Pitrich \& Meece, 2012).

Menurut Schunk, Pitrich dan Meece (2012) menjelaskan bahwa motivasi sangat berkaitan erat dengan Self-Regulated Learning. Pemelajar yang termotivasi untuk mencapai tujuan yang hendak dicapai tentunya akan melaksanakan aktivitas pengaturan diri. Proses menetapkan tujuan yang hendak dicapai merupakan fase awal dari Self-Regulated Learning.

\section{Self-Regulated Learning}

Pintrich (dikutip dalam Schunk, 2005) menjelaskan bahwa Self-Regulated Learning adalah proses konstruktif dari individu yang bersifat aktif dalam menetapkan tujuan pembelajaran yang hendak dicapai dan melakukan proses monitoring, pengaturan dan mengendalikan kognisi, motivasi dan perilaku serta dipandu oleh tujuan yang hendak dicapai.

Self-Regulated Learning berkembang dari teori kognisi sosial dari Bandura yang dikenal sebagai konsep segitiga triadic reciprocal. Konsep ini menjelaskan bahwa manusia merupakan hasil kausal yang terindependen dari pribadi, perilaku dan lingkungan (Zimmerman dikutip dalam Schunk, Pintrich \& Meece, 2012). Self-Regulated Learning membangun tujuan-tujuan yang hendak dicapai dalam proses belajar, mencoba untuk melakukan monitoring, membuat pengaturan yang baik, mengontrol kognisi, motivasi dan perilakunya untuk mengontrol tujuan yang dibuatnya.

Menurut Zimmerman (2000) menjelaskan bahwa Self-Regulated Learning terbagi dalam tiga tahap yakni (a) Forethought, (b) Tahap Performansi dan (c) Tahap Refleksi Diri. Tahap forethought terdapat dua bagian utama yang penting yakni analisis tugas dan keyakinan terhadap kemampuan diri atau self-efficacy. Tahap performansi juga mempunyai dua bagian utama yakni kontrol diri dan observasi. Pada tahap akhir yakni refleksi diri terdiri atas penelian diri dan reaksi diri.

\section{Self-Regulation Empowerment Program}

Self-Regulation Empowerment Program (SREP) disusun berdasarkan teori social cognitive dari Albert Bandura (Cleary \& Zimmerman, 2004). Self-Regulation Empowerment Program adalah program pelatihan yang diterapkan di sekolah dengan mengintegrasikan banyak esensi penting dari pendekatan pemecahan masalah dengan menggunakan siklus regulasi diri dalam belajar (Cleary \& Zimmerman 2004).

Tujuan pelatihan Self-Regulation Empowerment Program yakni (a) memupuk keyakinan selfmotivational yang positif, (b) meningkatkan pengetahuan individu mengenai strategi belajar dan (c) membantu individu untuk mengaplikasikan strategi tersebut pada tugas akademik secara mandiri. Self-Regulation Empowerment Program terdiri atas dua komponen yakni (a) pengukuran diagnostik atau diagnostic assessment melalui proses observasi dan wawancara dan (b) mengembangkan kemampuan mengatur diri dalam belajar atau developing the self-regulated learner. 
Penerapan intervensi Self-Regulation Empowerment Program pada dasarnya terbagi dalam 3 langkah yakni (1) Empowerment, (2) Memberikan pengajaran mengenai penerapan strategi belajar dan (3) Penerapan tiga fase regulasi diri dalam belajar. Esensi penting dalam modul SelfRegulated Empowerment Program yakni membangun kesadaran individu mengenai penyebab dari pencapaian prestasi akademik, meningkatkan kesadaran pembelajar mengenai pemahaman yang salah atau tidak sesuai tentang dirinya (Cleary \& Zimmerman, 2004).

Hal penting lainnya yakni meningkatkan kemampuan individu dalam merencakan tujuan, menyusun langkah-langkah strategis yang ditempuh untuk mencapai tujuan dan menganalisis tugas yang diberikan kepada pembelajar (Cleary \& Zimmerman, 2004).

\section{METODOLOGI PENELITIAN}

\section{Desain, Teknik Sampling dan Subyek Penelitian}

Desain penelitian ini yakni kuasi eksperimental dengan metode pengambilan sampel yang digunakan adalah pretest-posttest non-equivalent control group. Partisipan dalam penelitian ini adalah 18 mahasiswa non reguler dari Jurusan $\mathrm{X}$ yang terbagi dalam dua kelompok yakni 8 mahasiswa pada kelompok eksperimen dan 8 kelompok pada kelompk kontrol.

Berdasarkan data demografi, gambaran partisipan penelitian ini menunjukkan dari 18 partisipan sebanyak 6 partisipan atau sekitar $75 \%$ berjenis kelamin perempuan dan 2 partisipan atau sekitar $25 \%$ berjenis kelamin laki-laki. Selain itu, partisipan memiliki rentang usia dari 18 sampai 20 tahun dan seluruh partisipan merupakan mahasiswa semester 3. Hasil Indeks Prestasi Kumulatif (IPK) dari seluruh partisipan berada pada rentang 1,5 - 2,4.

\section{Pengukuran}

Teknik analisis yang digunakan pada penelitian ini yakni uji perbedaan dua kelompok MannWhitney. Pada penelitian ini, Alat ukur yang digunakan yakni motivasi berprestasi yang disusun berdasarkan ciri-ciri orang yang mempunyai motivasi berprestasi (McClelland, 1987) yakni (1) suka bekerja kejas, (2) ulet, (3) membutuhkan umpan balik secara nyata, (4) berorientasi pada masa depan, (5) tidak suka membuang waktu, (6) optimis, (7) bertanggung jawab dan (8) memperhitungkan resiko.

Alat ukur motivasi berprestasi telah digunakan oleh Adzani (2012) yang meneliti perihal hubungan motivasi berprestasi dengan perilaku procrastination. Alat ukur ini disusun berdasarkan skala likert yang memiliki pilihan jawaban sangat setuju, setuju, netral, tidak setuju, dan sangat tidak setuju. Pada tahap pengujian alat ukur diperoleh realibilitas alat ukur ini melalui internal consistency (Cronbach Alpha) menunjukkan skor 0.82 .

\section{Program Intervensi}

Intervensi dilakukan dalam delapan sesi dengan rentang waktu 11 Oktober 2016 sampai dengan 25 Oktober 2016. Program intervensi disusun berdasarkan tahapan Self-Regulation Empowerment Program (Cleary \& Zimmerman, 2004) yakni melaksanakan sesi empowerment dan mengimplemenbtasikan tiga tahapan Self-Reguated Learning.

Intervensi pada sesi satu diawali dengan pengukuran data pre-test melalui alat ukur motivasi berprestasi. Selanjutnya pemeriksaan dilakukan dengan menggunakan beberapa alat tes psikologi untuk mengetahui kapasitas kecerdasaan dan motif berprestasi yakni TIKI Tinggi, WZT dan EPPS. Pada sesi kedua, dilaksanakan aktivitas bertajuk "Penyebab Kegagalanku". Pada sesi 
ketiga, peneliti memberikan materi motivasi diri melalui tayangan video dan meminta partisipan menuliskan hal-hal yang dipetik dari video tersebut dan komitmen yang dapat dilakukan dalam kehidupan sehari-hari.

Sesi berikutnya yakni sesi empat, peneliti menyampaikan pemahaman mengenai self-regulated Learning dan meminta partisipan untuk mengisi lembar kerja. Pengisian lembar kerja dilakukan dua kali yakni sebelum materi disampaikan dan sesudah materi diberikan. Pada sesi kelima, peneliti meminta para partisipan untuk menyusun goal setting sebagai implementasi dari tahap forethrought pada Self-Regulated Learning.

Pada sesi keenam, peneliti menyampaikan materi time management sebagai implementasi dari tahap performansi yang merupakan tahap kedua dari Self-Regulated Learning. Pada sesi ketujuh, peneliti memberikan materi evaluasi dalam bentuk refleksi diri terhadap keberhasilan dan hambatan yang dialami dalam mencapai tujuan. Sesi terakhir atau sesi ke delapan, peneliti melaksanakan tahap post-test yakni memberikan kembali alat ukur motivasi berprestasi untuk mengetahui penerapan program intervensi Self-Regulation Empowerment Program dapat meningkatkan motivasi berprestasi.

\section{HASIL DAN PEMBAHANSAN}

\section{Hasil perbandingan motivasi berprestasi pre-test antar kelompok}

Pengambilan data pre-test dilaksanakan pada Jumat, 14 Oktober 2016 yakni meminta partisipan yang telah terbagi dalam 2 kelompok yakni kelompok eksperimen dan kelompok kontrol. Aktivitas dilanjutkan dengan mengisi kuesioner motivasi berprestasi. Saat kuesioner tersebut dibagikan, peneliti menyampaikan bahwa masing-masing partisipan diminta untuk mengisi setiap item sesuai dengan kenyataan dan kondisi yang dialami seluruh partisipan.

Tabel 1. Hasil Perhitungan Mann-Whitney Tahap Pre-Test

\begin{tabular}{|c|c|}
\hline \multicolumn{2}{|c|}{ Test Statistics ${ }^{\mathrm{a}}$} \\
\hline & Pre-test \\
\hline Mann-Whitney U & 23,500 \\
\hline Wilcoxon W & 59,500 \\
\hline $\mathrm{Z}$ &,- 896 \\
\hline Asymp. Sig. (2-tailed) & ,370 \\
\hline Exact Sig. [2*(1-tailed Sig.)] & $382^{\mathrm{b}}$ \\
\hline
\end{tabular}

Berdasarkan data tabel 1 mengenai pre-test melalui perhitungan Mann-Whitney menujukkan $\mathrm{Z}$ skor $-0,896$ dan $p=>0,05$. Hal ini menunjukkan tidak terdapat perbedaan pada kelompok eksperimen maupun kelompok kontrol pada tahap pre-test.

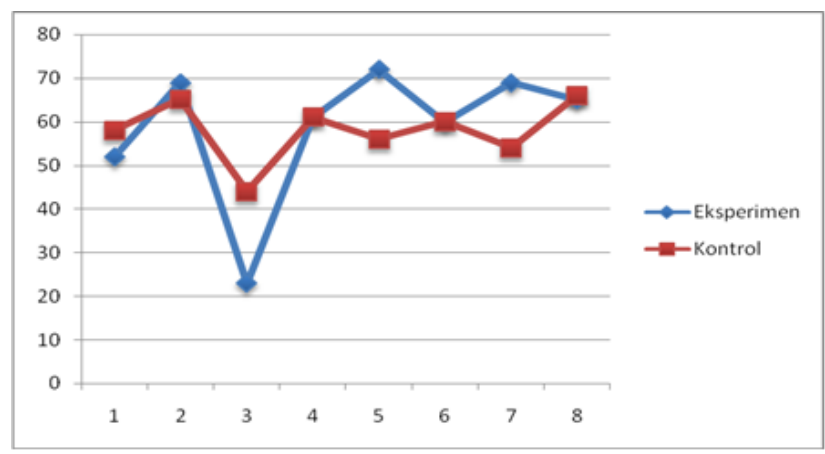

Graffik 1. Perbandingan Hasil Pre-test Antar Kelompok 


\section{Hasil perbandingan motivasi berprestasi post-test antar kelompok}

Hasil post-test dihitung dengan membandingkan kelompok eksperimen dan kelompok kontrol. Perhitungan statistik yang digunakan yakni Mann-Whitney karena jenis data ordinal dengan tujuan pengukuran untuk mengukur perbedaan. Berdasarkan perhitungan uji beda didapatkan hasil sebagai berikut:

Tabel 2. Hasil Perhitungan Mann-Whitney tahap Post-Test

\begin{tabular}{|c|c|}
\hline \multicolumn{2}{|c|}{ Test Statistics $^{\mathrm{a}}$} \\
\hline & Post-test \\
\hline Mann-Whitney U & 11,000 \\
\hline Wilcoxon W & 47,000 \\
\hline $\mathrm{Z}$ & $-2,210$ \\
\hline Asymp. Sig. (2-tailed) & ,027 \\
\hline Exact Sig. [2*(1-tailed Sig.)] &, $028^{\mathrm{b}}$ \\
\hline
\end{tabular}

Dari tabel 2 mengenai uji beda dengan Mann-Whitney di atas diperoleh $\mathrm{Z}=-2,21$ dengan $p<$ $0.05 \mathrm{Hal}$ ini menunjukkan bahwa terdapat perbedaan setelah intervensi diberikan antara kelompok eksperimen jika dibandingkan dengan kelompok kontrol artinya pemberian intervensi Self-Regulation Empowerment Program dapat meningkatkan motivasi berprestasi pada mahasiswa non regular, Jurusan X, Universitas X.

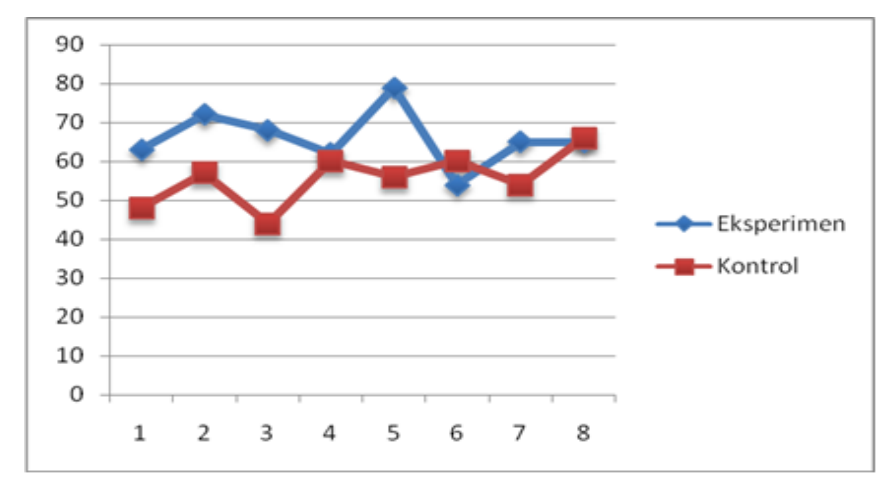

Graffik 2. Perbandingan Post-Test antar Kelompok

\section{Hasil perbandingan motivasi berprestasi Pre-test dan Post-test Kelompok Eksperimen}

Pengambilan data pre-test dilaksanakan pada Jumat, 14 Oktober 2016. Sementara itu, post-test dilakukan pada 14 November 2016 sehingga jangka waktu antara pre-test sampai post-test yakni 1 bulan.

Tabel 3. Perbandingan Hasil Pre-test dan Post-test Kelompok Eksperimen

\begin{tabular}{ccccc}
\hline $\begin{array}{c}\text { Subyek } \\
\text { Eksperimen }\end{array}$ & $\begin{array}{c}\text { Skor } \\
\text { Pre-test }\end{array}$ & $\begin{array}{c}\text { Skor } \\
\text { Post-test }\end{array}$ & Gain Score & Keterangan \\
\hline SA & 52 & 63 & 11 & Meningkat \\
AZ & 69 & 72 & 3 & Meningkat \\
FK & 23 & 68 & 45 & Meningkat \\
AS & 61 & 62 & 1 & Meningkat \\
EA & 72 & 79 & 7 & Meningkat \\
ISA & 60 & 54 & -6 & Menurun \\
WS & 69 & 65 & -4 & Menurun \\
YL & 65 & 65 & 0 & Tidak berubah \\
\hline
\end{tabular}


Berdasarkan tabel 3, 5 dari 8 partisipan atau sekitar 62\% yakni SA, AZ, FK, AS dan EA mengalami peningkatan pada skor total motivasi berprestasi setelah intervensi diberikan. 1 partisipan atau sekitar $12,5 \%$ mempunyai total skor yang sama dan 2 partisipan lainnya atau sekitar 25\% yakni ISA serta WS mengalami penurunan skor total motivasi berprestasi. Merujuk dari persentase sebesar $65 \%$ mengalami peningkatan motivasi berprestasi, maka dapat disimpulkan bahwa mayoritas subyek mengalami peningkatkan motivasi berprestasi

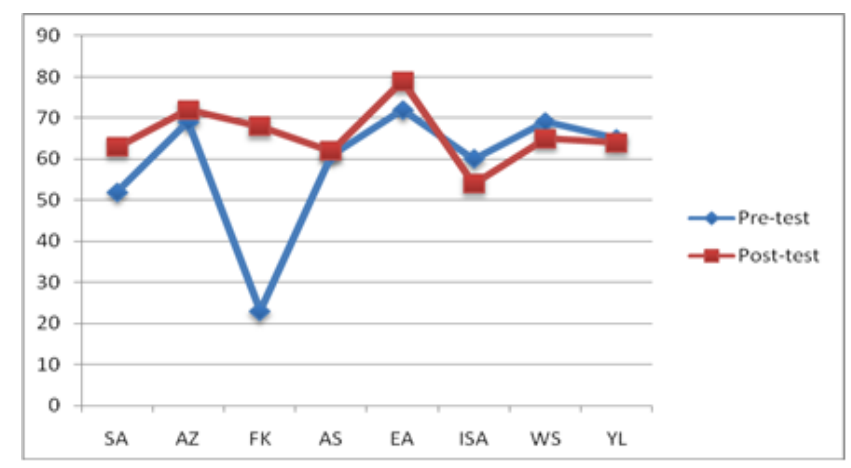

Graffik 3. Perbandingan Pre-test dan Post-test Kelompok Eksperimen

\section{Pembahasan}

Berdasarkan tujuan penelitian ini yakni meningkatkan motivasi berprestasi mahasiswa non reguler melalui Self-Regulated Empowerment Program serta didukung oleh data yang menunjukkan total skor pre-test dan post-test pada kelompok eksperimen menyatakan 5 dari 8 partisipan atau sekitar $65 \%$ mengalami peningkatan motivasi berprestasi dan hasil perhitungan uji beda menggunakan Mann-Whitney pada tahap post-test menunjukkan bahwa terdapat perbedaan antar dua kelompok yakni terjadi peningkatan motivasi berprestasi pada kelompok eksperimen dibandingkan kelompok kontrol. Hal ini menunjukkan bahwa intervensi SelfRegulated Empowerment Program yang dilakukan terhadap kelompok eksperimen berhasil meningkatkan motivasi berprestasi.

Keberhasilan intervensi ini dalam meningkatkan motivasi berprestasi tentunya sangat terkait dengan tujuan dari program ini. Menurut Cleary dan Zimmerman (2004), tujuan dirancangnya program Self-Regulation Empowerment Program yakni meningkatkan motivasi intrinsik dari setiap individu sehingga dapat membantunya dalam mencapai prestasi akademik.

Self-Regulation Empowerment Program dapat meningkatkan motivasi berprestasi, hal ini sejalan dengan beberapa penelitian yang dilakukan oleh Pintrich dan De Groot, (1990); Zimmerman, Bandura dan Martinez, (1992); Zimmermean, et al, (1992) (dalam Lhay \& Sarkeshikian, 2015) menjelaskan bahwa motivasi berprestasi individu dihasilkan dari penggunaan Self-Regulated Learning.

Keberhasilan dalam meningkatkan motivasi berprestasi para partisipan juga tidak terlepas dari penguatan pada faktor internal yakni mengajarkan langkah-langkah menyusun goal setting dan memperkuat motivasi atau keyakinan akan kemampuan para partisipan. Hal ini Sejalan dengan McClelland (dalam Haryani \& Tarias, 2014) faktor internal dalam diri individu yang memengaruhi motivasi berprestasi yakni self-efficacy, task value dan goal setting.

Adapun faktor lainnya yang juga memengaruhi keberhasilan ini berdasarkan hasil evaluasi yakni situasi dan kondisi yang kondusif pada setiap pelaksanaan sesi yang dijelaskan dengan suasana 
cenderung tenang, jauh dari sumber kebisingan. Selain itu, kelengkapan peralatan pada setiap sesi juga mendukung keberhasilan intervensi ini.

\section{KESIMPULAN DAN SARAN}

\section{Kesimpulan}

Berdasarkan pelaksanaan seluruh program intervensi yang disusun dalam 8 sesi dan hasil perhitungan uji beda dengan mann-whitney menunjukkan perbedaan antar kelompok pada tahap post-test, maka dapat disimpulkan bahwa pelaksanaan intervensi Self-Regulation Empowerment Program dapat meningkatkan motivasi berprestasi mahasiswa non reguler, Jurusan X, Universitas X.

\section{Saran}

\section{Saran Metodologis}

Sebelum melaksanakan program intervensi melalui modul kepada partisipan, sebaiknya dilakukan uji keterbacaan kepada orang lain yang tentunya mempunyai latar belakang pendidikan, usia dan kemampuan yang setara.

Perlu mempertimbangkan mengenai hari dan waktu pelaksanaan intervensi dengan mengetahui jadwal kuliah masing-masing partisipan untuk penelitian selanjutnya.

Penelitian selanjutnya dapat melatih kemampuan partisipan pada beberapa aspek disetiap tahap karena pada penelitian ini hanya melatih kemampuan partisipan pada satu aspek pada masingmasing tahap.

Saran teoritis yang diberikan bagi perkembangan ilmu psikologi yakni melalui hasil penelitian ini dapat memperkuat secara teoritis bahwa Self-Regulated Learning yang diimplementasikan melalui intervensi Self-Regulation Empowerment Program mampu meningkatkan motivasi berprestasi.

Bagi penelitian selanjutnya yang hendak meneliti mengenai motivasi berprestasi melalui intervensi Self-Regulation Empowerment Program dapat dilakukan sampai tahap follow-up.

\section{Saran Praktis}

Saran bagi partisipan yakni berkomitmen untuk hadir dalam seluruh pertemuan kuliah. Partisipan diharapkan aktif bertanya jika ada materi yang kurang dipahami. Partisipan diminta untuk dapat mengatur waktu dengan baik dan menetapkan tujuan secara jelas. Partisipan diminta untuk meluangkan waktu setiap hari secara rutin untuk belajar.

Saran bagi orangtua yakni meluangkan waktu untuk menanyakan aktivitas atau bahkan kemajuan dari pengerjaan tugas-tugas kuliah. Orangtua dapat memonitoring terkait kehadiran rutin anaknya di kelas dengan melihat website yang telah disediakan oleh Universitas X.

Saran yang diberikan bagi unit di Universitas $\mathrm{X}$ yakni mengimplementasikan modul ini yang telah terbukti dapat meningkatkan motivasi berprestasi pada mahasiswa non reguler kepada mahasiswa non reguler lainnya. 


\section{REFERENSI}

Andranita, M. (2013). Program intervensi self-regulation empowerment program untuk meningkatkan regulasi diri pada siswa underachiever tipe coasting. Tesis tidak diterbitkan, Magister Ilmu Psikologi, UNiversitas Tarumanagara, Jakarta.

Adzani, N. (2012). Hubungan motivasi berprestasi dengan prokrastinasi Akademik. Skripsi tidak dipublikasikan. Universitas Bina Nusantara, Jakarta.

Alfiana, A, D. (2013). Regulasi diri pada mahasiswa ditinjau dari keikutsertaannya dalam organisasi kemahasiswaan. Jurnal Ilmiah Psikologi Terapan, 01(02), 245 - 259.

Cleary, T. J. \& Zimmerman, B. J. (2004). Self-regulation empowering program: A scholl-based program to enchanceself-regulated and self-motivation Cycles of student learning. Journal Psychology in school, 41(5), 537-550. DOI: 10.1002/pits.10177.

Cleary, T, J., Platten, P., \& Nelson A (2008). Effectiveness of the self-regulation Empowerment program with urban high school student. Journal of Advance Academic, 20(1), 70-107.

Feist, J \& Feist, G.J. (2009). Theory of personality (7 ed). New York, NY: McGraw-Hill.

Gunarsa, S. D. (2008). Psikologi olahraga prestasi. Jakarta: BPK Gunung Mulia.

Haryani, R \& Tarias, M. M. (2014).Motivasi berprestasi pada mahasiswa Berprestasi dari ekluarga tidak mampu secara ekonomi. Jurnal Psikologi Pendidikan dan Perkembangan, 3(1), 30-36.

Latipah, E. (2010). Self-regulated learning dan prestasi belajar: kajian meta analisis. Jurnal Psikologi, 37(1), 110-129.

Lhay, H. A \& Sarkeshikian, S. A. H. (2015). Motivational facets of self-regulated Learning: selfefficacy as a predictor of resource management strategies In Iranian TEFL student. Journal of scientific Research and Development, 2(5). 203-210.

Mc Clelland D. C.(1987). Human motivation. England: Cambridge University Press.

Purwanto, E. (2014). Model motivasi trisula: Sintesis baru teori motivasi Berprestasi. Jurnal Psikologi, 41(2), 218-228.

Puteri, R.R. (2013). Intervensi Self-Regulation Empowerment Program untuk meningkatkan regulasi diri pada siswa underachiever tipe if-then students. Tesis tidak diterbitkan, Magister Ilmu Psikologi, UNiversitas Indonesia, Depok.

Schunk, D, H. Pintrich, P, R \& Meece, J, L. (2012). Motivasi dalam pendidikan teori, penelitian dan aplikasi. (edisi ke-3). Tjo E (Penerj). Jakarta: Ind

Zimmerman, B.J. (2000). Attaiment of self-regulation: A social cognitive Perspective. IN M. Boekaerts \& PR pintrich \& M Zeidner (Eds) Hand book of self-regulation $2^{\text {nd }}$ Ed.

Zimmerman, B.J. (2001). Theories of self-regulated learning and academic achievement: An overview and analysis. 